\title{
Gender Representation In Public Schools Textbooks Of Balochistan
}

\author{
Rana Saba Sultan \\ \& \\ Nadil Shah \\ Department of Sociology \\ University of Karachi, Pakistan \\ Ambreen Fazal \\ Department of Media Studies \\ Sindh Madressatul Islam University
}

\begin{abstract}
Gender became the attention of contemporary scholarships when women were found in domestic issues as well as gender inequality in terms of job opportunities, education, health, political participation etc. Many studies have been carried out regarding women issues and provided policies and laws to provide opportunities for women to contribute in the society. So, gender presentation in school textbooks is newly emerging field of study in the academia. The present study focuses on women presentation in school textbooks of Balochistan. The English Books for Class I, to V were taken as sample for present study. These books were selected through purposive sampling. All conversations, texts and images related to women misrepresentation were taken from selected books. These data were analysed by the help of Michal Foucault's theory of power/Knowledge and Discourse Analysis and also Cultural Hegemony by Antonio Gramsci. The findings of the present study suggest that textbooks of Balochistan are clearly misrepresenting women and promoting the male hegemony. The women are shown in domestic works and teaching jobs which are considered soft works. On the other hand, men are shown in school administrations, public domains, ownerships and in those jobs which need more power and energy. So, it is clear that schools textbooks promote the gender biased approach because men are shown in powerful, prestigious, well reputed and respectable jobs and women are shown in less respected and less valued positions.
\end{abstract}

Keywords: Balochistan, Textbooks, Gender, Cultural Hegemony, Power/ Knowledge, Discourse.
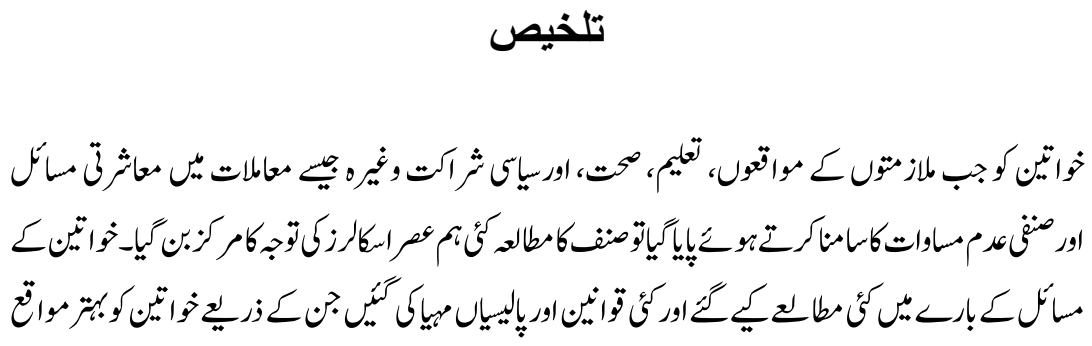


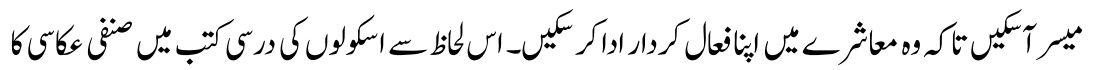

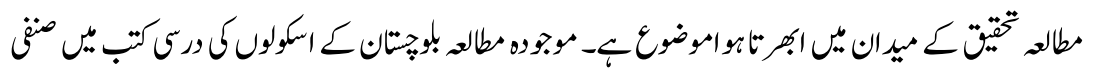

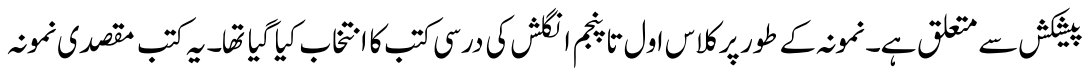

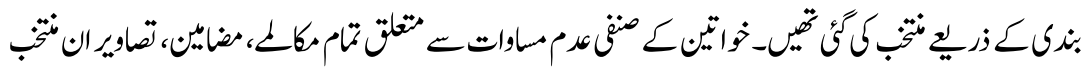

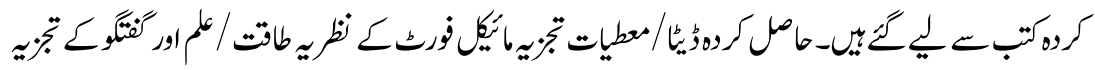

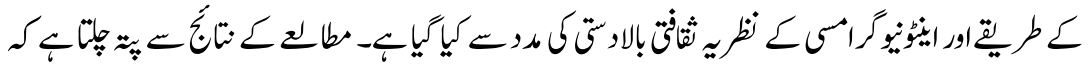

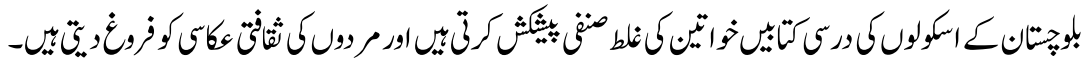

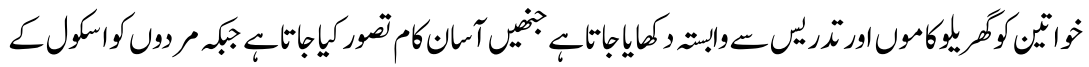

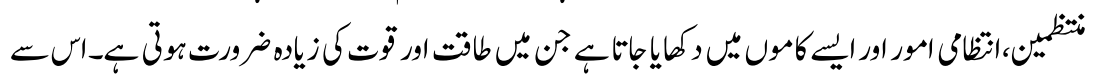

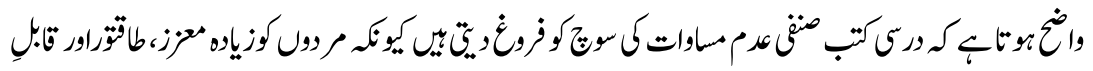

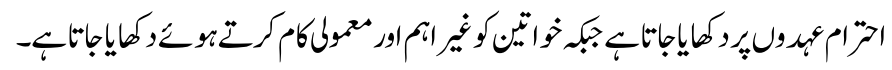

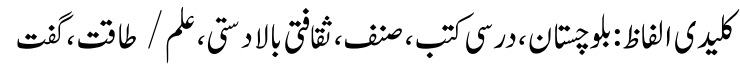

\section{Introduction}

Textbook is defined as "a book used as a standard work for the study of a subject (i.e. Urdu, English, Science etc.) (Simpson \& Weiner, 1989,P. 1483)". These textbooks are the main sources of socialization of young generation. By study these books, children to know about their heroes, history as well as their material and non-material culture. Instead of these, they also learn their statuses and roles such as father who is breadwinner or judge who can make decisions of other family members. On the other hand, girls learn the role of mother such as cleaning, caring and cooking etc from these books because textbooks are usually reflect or represent the social structure of society to the children. Society will function effectively if the young generation learns and adopts these statuses and roles in their daily lives. As Michal Foucault (2012) argued that school is one of the disciplinary institutions which can create a disciplinary society because the children are taught their roles by the educational institutions in the shape of images, conversations and stories in the textbooks which are instructed by the state/government. This study explores the Gender stereotypes for female (i.e. dependent, submissive, follower) and for male (i.e. Courage, independent, competent and leader) portrayed in images and stories or characters in children's textbooks. Stereotype is defined "an image or idea of a particular type of person or thing that has become fixed through being widely held (Oxford English Dictionary, 1989, p. 1408)" and gender stereotype refers to fixed ideas and beliefs about males or females which are mostly not correct such as for female: unintelligent, silly, emotional etc or sometimes based on 3Cs (Caring, 
Childrearing and Cleaning) and for male: intelligent, rational, strong etc. Therefore, these stereotypes are taught to the children by teachers through the recommended schools textbooks.

Textbooks are the only sources where children learn their cultural traits and construct their social world. These textbooks are shaped by men as well as women but the patriarchal structure is dominated though women are the part of curriculum developing but they are cannot question and they are vulnerable. The vulnerability of women gives the chance to men to create gender stereotypes/ biasedness and add those materials which support the interest of men or patriarchal structure of society. Due, which these are full of hidden traditional gender, stereotypes, statues etc. As Stromquist, Lee \& Brock-Utne (1998) argued that the textbooks are the main source of gender socialization due to which hidden gender stereotypical messages are taught to the children through these textbooks. This study tries to discover how the men use education to maintain their dominance in the society.

As Marxist believed that education is a tool used by Haves to exploit Havesnot and maintain the exploitative social structure. Same is the case with Education and Men. Education is a tool used by men to exploit women and the contribution of women in the development of society is completely hidden on the pages of textbooks. This study was conducted in Balochistan and critically reviewed the textbooks of Balochistan Text Book Board, Quetta, and how gender stereotypes are presented in these books.

\section{Literature Review}

Education being one of the social institutions and an agency for socialization of younger generation. It's plays a pivotal role in shaping the social structure of a society which is very important for smooth functioning of society. As functionalist like Talcott Parson and Emile Durkheim believed, that education bring universality in values, transformation of culture to the next generation and bring strong solidarity and it is maintenance of morality of a society (Faiz, 2015). On contrary, Education is also successive tool used to maintain the class society where oppressor benefits more and they maintain their dominance on civil society. As James M. Henslin (1981) writes in his book Essentials of Sociology: A downto-earth Approach that Conflict theorists believe that education is the tool used by elite to exploit the poor. This approach is not only limited to the elite rather it is also used by men to maintain their dominance on women through textbooks, gender socialization in day to day lives and through other domestic roles and status to women.

Gender stereotype is practiced in all social institutions such as politics, education, health, media, and economy by men against women. It is greatly practiced in education such in hidden curriculum -teaching materials which are taught to the 
students in the class but actually they are not written in the syllabus-(Henslin et al., 2015) and as well as through the textbooks which are tough in each levels of the students in educational institutions. The textbooks have important roles in socialization of young generation because all the social norms, values and the social structure is represented and promoted through these textbooks. Taylor (2003) gives Similar, argument about gender role. As he said that textbooks are the main sources by which children, learn their respective gender roles such as mothering for females and breadwinning for male. Kittelberger (2002) also agreed that gender stereotype is constructed through books by using gender discriminatory languages, pictures, contents and illustration in children's textbooks. Further Ya-Lun Tsao said that most of male characters are titles, pictures and texts but female are not only underrepresented but also they are portrayed as unimportant in the children's books (2008).

It is usually showed in the children's textbooks that women or girls have less important roles in the society than the men or boys (McCabe et al, 2011) because they are portrayed in less important roles in school textbooks (Weitzman et al, 1972). Stacay, Chick and Kendal (2006) also gave related argument about gender role as she said that in U.S history textbook of K-Grade 12, women roles in the contribution in the world wars is usually neglected in history textbooks of America. Further, McCabe et al, (2011) write that patriarchal structure of society is legalized, reproduced and maintained through the textbooks which are taught to the young generation. Moreover, Books are the main sources of gender socialization and shaping the gender identities through which the thinking and acting pattern of children are shaped according to broader social structure.

It is clear that teaching and reading these gender-biased materials engender the self-identities of children. Moreover, by learning these gender biases from books, children try to adopt those roles and behaviours, which will become the part of their socialization process (Tsao, 2008). Because reading these texts, children construct their ideas and compare the learned knowledge to the external structure of society and finally they construct their own ideologies, beliefs and values (Mendoza and Reese, 2001, cited by Ya-Lun Tsao, 2008). As Singh (1998) argued that by accepting these ideologies, children make their own self-images and act according to learned image such as girls consider herself women and boy as men. These pictures and language of books greatly affects their development because it is their learning and development age. Despite perpetuating ideologies, textbooks also portray gender roles in which women are assigned traditional gender roles, which are less important in the society.

In children schools books male characters are shown more potent, powerful and active than women. So, these gender stereotypes are hurdle on the ways of girls for being the role models in the society (Tsao, 2008). In the pictures of conventional places, female are assigned passive roles and male are active. 
Female are shown dependent, silly, emotional, clumsy and lacking intelligence in the textbooks. So, Trepanier-Street and Romatowski (1999) said that it is possible to influence the children attitudes through the children's literature by portraying such gender roles in images of textbooks. On contrary, Koble and La Voie (1981) said that children books not only reproduce gender stereotypes rather these can eliminate the sexism and gender discrimination if equal or positive gender roles are portrayed in children's textbooks. Similarly, arguments developed by other researchers and they said that teaching egalitarian books can change the gender attitudes and beliefs of children through a period of time (Barclay, 1974; Trepanier-street and Romatowski, 1999 cited by McCabe et al, 2011). Many pieces of research are available around the world about Gender representation in children's textbooks as mentioned above. Likewise, some researches were also conducted in Pakistan about textbooks and gender representation in Pakistani textbooks.

Pakistan, being a developing country, with less education ratio, adequate literature available where gender disparity exists. From children's textbooks to the other general books such as about history etc. Many sociologists and educationalist questioned despite this phenomena exist in Pakistani textbooks. Khurshid et al (2010) conducted a research on representation of female images in Urdu and English textbooks and found that women are working in private domain such as housewives and home-related activities and men are working in public domain such as political or religious leaders and breadwinner etc. This research depicts that women are only limited to home and leading qualities and earning is responsibility attached to men. A similar study has been conducted on textbooks of Khyber Pakhtunkhwa by and found that women/girls are greatly underrepresented in children textbooks (Ullah \& Skelton, 2013). Further, they argued that men are given authoritative positions in the images of children's books and women are given traditional gender roles such as mothering, caring, and cooking etc. Additionally, Jabeen \&Ilyas (2012) carried out a research on gender modelling in Textbooks in Sindh Province argued that women roles are limited to nurturing, cooking, cleaning and sewing in Pakistani textbooks. Despite these traditional roles and stereotypes, images and texts in children's textbooks also depict gender disparity in games.

Further, Ullah and Skelton said that they did not only found the traditional gender roles and stereotypes in education, housework etc rather they had found that there is great gender biasedness in sports as well. As they found that girls were portrayed as playing with dolls, or swinging in the water but boys are playing football, hockey, and cricket (2013). Hazir Ullah (2016) also carried out another research on textbooks and gender about teaching domain where he founded that children textbooks portrayed images where it is showed that teaching in primary schools is a profession for women and universities for men because primary is directly attached to the domestic positions where children need love and care and university teaching harder or far from village which performed by men. The studied literature proves that gender stereotype exists in all schools textbooks in 
the world and these materials should be reformed for creating an egalitarian and proper society in national and international level.

\section{Theoretical Framework}

For this study, Discourse Analysis will be used to analyse these text and images of textbooks. Discourse analysis is used by scholars and researchers to analysis any social phenomenon to know the hidden messages behind any text. This approach believes that how power is established and reinforced by language. For Foucault (1980), it is "through discourse (through knowledge) that we are created; and that discourse joins power and knowledge, and its power follows from our casual acceptance of the "reality with which we are presented" (Pitsoe \& Letseka, 2013, p. 24; Shah, Sultan \& Kaker, 2018). The main concern of discourse is to know the power relation and how powerful create biased and stereotypical discourse to exercise their power on the weaker segment of society or propagate their ideology. Here powerful means men and the weaker segment of society are women. Foucault also believed that morality, truth, and meanings are constructed through discourse (Pitsoe \& Letseka, 2013). This study tries to know, how men are using schools textbooks against women to main their dominance in the existing social system. How school textbooks portrayed those pictures and texts which present traditional roles and status on the base of sex. Despite, discourse and power/knowledge, the theory of hegemony by Antonio Gramsci was used for analysing the data because this theory gives the critical lens to the researcher to find out the hidden ideologies and politics behind any text shown in books, media or other sources to the public. Gramsci defined as culture hegemony -rules and regulations, which are implemented by elite/political society on civil society and civil society, believe that these are their benefits but actually, they may not be (Anderson, 1981). Further, Terry Eagleton (1991) writes that for Gramsci 'hegemony means the dominant power wins consent to its rule from those it subjugates'. In Hegemony, “oppressed class gives permission to oppressors to oppress them" (Pitsoe and Letseka, 2013, p. 24).

\section{Method of the Study}

The Textbooks of Balochistan are taken for the present study as unites of analysis because very little researches have been conducted on this area, which is a hard topic in the context of Balochistan. The textbooks of class I to V were taken in the present study because these books are more important in children's socialization. In this age, a child can learns most of the cultural traditions from society coupled with information and knowledge receives from schools as well as peer groups within the schools. Inclusively, English Textbooks of these classes were taken for the study because these were easier for the researcher as well as the official language of the country. Secondly, English language is considered a more liberal language, by teaching English to the children; they would become more modern 
and liberal. Despite this, how textbooks are going toward contrary to predetermined beliefs and propagating the traditional mindsets. Moreover, Qualitative approach was used for carrying out the current study. There were two reasons of taking this approach. First, all data were images, conversations and textbooks. Such data need deep critical analysis by the interpretation of researchers. Secondly, the researchers' expertise was in this method. The researcher also selected Purposive sampling technique for selection of textbooks because it allows researchers to select those materials, which are very important and appropriate for the ongoing project. Finally, Antonio Gramsci (See theoretical framework) analyzed data through the theory of Michael Foucault Discourse and Power/Knowledge and theory of Culture hegemony.

\section{Findings and Results}

\section{Promoting Male Supremacy in Schools Textbooks}

Textbooks promote and protect the male supremacy. It can be seen from the text in a school children book that a six year boy setting around a table with his all family members and introduces his family.

My name is Saad. I am six years old. I have six members in my family. My grandfather and grandmother love us. I have a brother and a sister. My father is a doctor. My mother is a house wife. We love each other (Unite No 4. I and My family. English Book for Class I, page. 34).

Similarly, females are believed to work in private sphere and males are responsible for public sphere. Males are breadwinner and they are responsible to buy the goods for family from markets and being a shopkeeper is also a male oriented work. As shown in English book for Class I, Page. 50) two small boys meet each other in front of a fruit and vegetable shop and they are conversing with each other.

Ali:AssalamoAlaikumMasood, how are you?

Masood:WalakumAssalam, I am fine! Thank you.

Ali: I am here to buy fruits for my gusts.

Masood: And I am here to buy vegetables for dinner.

Ali: Do you like fruits too?

Masood: Yes, I do. Fruits are good for health.
Ali: Which fruits do you like most?

Masood: I like apples and bananas.

Ali: But I like Mango. It is called the King of all fruits.

Masood: Uncle, please give $1 \mathrm{~kg}$ turnips and $2 \mathrm{~kg}$ potatoes.

Ali: Please give $2 \mathrm{~kg}$ mangoes and one dozen bananas. 
Likewise, females are depicted with temporary, love and soft objects. On other hand, male are attached with hard jobs and ownership in Children's school textbooks.

She has a cat. They (two boys) have a football. He has a ball. I (a boy) have a bat. We (two men) have a big house (English 1, Page. 60).

Cat is attached with female because cats are believe to be innocents and loved by everyone. On other hand, male are attached with football, ball, bat and big house. Football and Cricket are considered male games because these games need a lot of energy and physical power. The society believes that women have no capacity to play these games. Moreover, the concept of ownership is also attached with male due to which only men are the owner of houses and women are alike guests who would come or go after her marriage.

\section{Gendering the Roles}

Roles are given according to the gender of the individual because roles are socially constructed. Women are portrayed with traditional 3Cs (Caring, Cleaning and Childrearing) (Henslin, 1981) while men are represented as owners, strong, independent, responsible for family affairs and other socially respected positions in the society. As mentioned in English Book for class II (P. 59)

Sadaf has a doll. Ajmal has a book

Similar gender biased role are shown in a picture in English Book for class II (P. 97)

My mother can cook food. She cannot play tennis.

He can drive a car.

Above, both statements are clearly showing the gendering the roles according to his or her sexual orientation. In first statement Sadaf (girl) is attached with doll and Ajmal (boy) is with book because Ajmal need to get education and should get a lucrative job for running the family in future. A detailed story is presented in English book for class $I V$ (P. 19) which is totally based on gender biased discourse.

Sana is a student of class four. She has three brothers and two sisters. Her father is a laborer. He wants his children get education. Sana, her brothers and sisters work hard to fulfill their father's dream.

She is a brilliant student. She always gets a good position in her class. She takes part in the debate competitions. She has taken good positions in different debate competitions. She respects her teachers very much. She is a very obedient student. Her behaviour is good with everyone at school. She always abides by the time and does her work properly. She helps her class fellows. She knows the safety precautions for playing in the school ground and takes care of herself and others. She also 
tells her class fellows to take care of others while playing and running.

In the evening, she completes her school work and learns her lessons. She also helps her younger brothers and sisters in their studies. She teaches them all subjects every day.

She also helps her mother in the kitchen and waters the plants. She spends some time with her grandmother and goes to bed early at night.

The above-mentioned story clearly depicts the gender-biased roles. It is a story of a girl who is study in $4^{\text {th }}$ class. First paragraph represents the hegemonic power of father where all family members act according to the expectations of him. Second paragraph is showing that girls should be obedient. Third paragraph depicts that women should play the role of caring and look after others. In Fourth Paragraph, it is showing that women are responsible for all family internal affairs. In fifth, It is showing that cooking and running the kitchen is the responsibly of females in home.

\section{Caring is a Female Job}

Traditionally, the role of a woman is to be the servant of man, which is very common in South Asian countries. Because caring for children, making children ready for schools, ironing the clothes of husband/brother responsibility of women in the home.
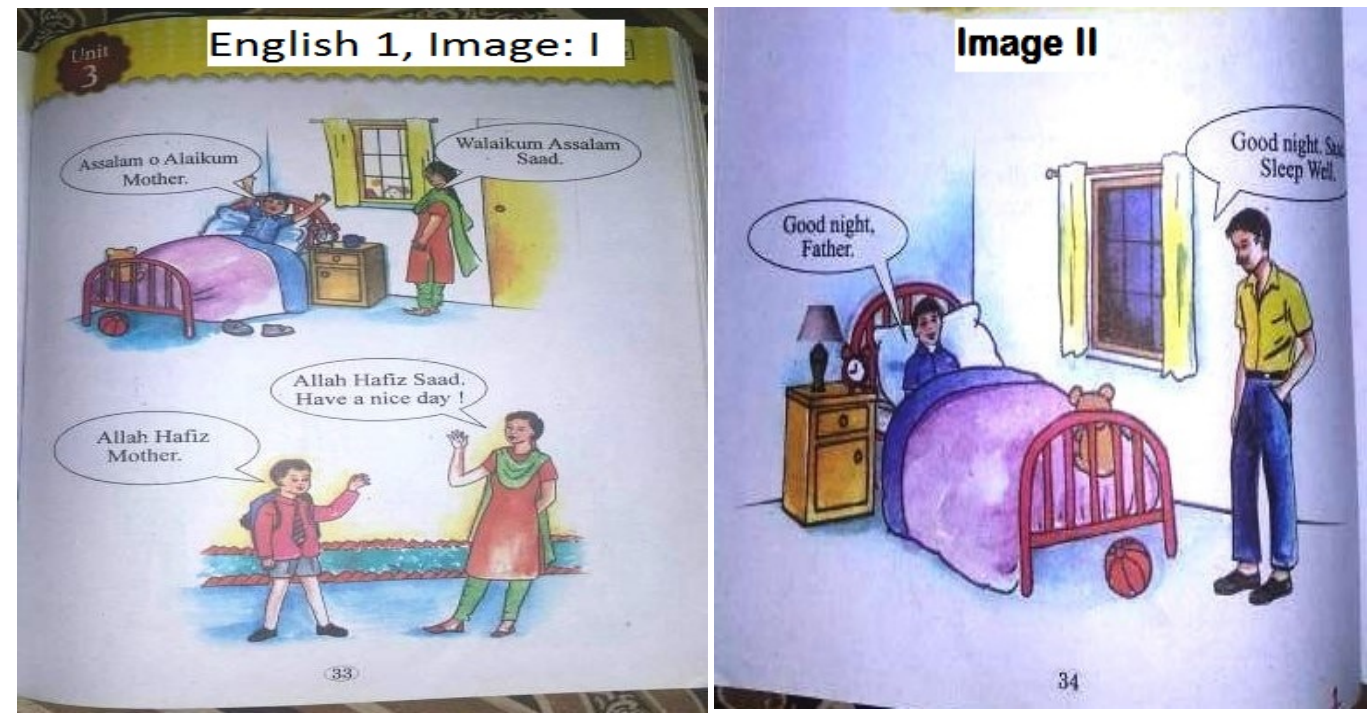

Image I and II clearly represent the same scenario, taken from English 1, taught to students of first grade students of public schools of Balochistan. There are two conversations shown in this picture. In the first one, a small boy is sleeping in bed and mother wakes him up. In second, a child is going to school and mother is saying goodbye. This picture is clearly showing caring the children is the job of a female (Mother) in the home. As common in our society, the mothers get up early and prepare breakfast for family members. After which she wakes up all the children and make them ready for schools, feed them breakfast and sometimes 
children are taken to school by her if a school is near to home. Similar, message is communicated in Image I. In first conversation, Mother has prepared breakfast and went to Saad to wake him. In second conversation, she has fed breakfast and made him ready for school. Image ii is also taken from the same book in which father is standing near the bed of his son and asking him to sleep well and the child is responding the father with respect. If both pictures are compared, the traditional gender role is reproduced which we can say that caring is the job of female. The most important thing in both pictures are time difference. The mother has visited her son on morning and father on night because feeding breakfast, making him ready for school is the job of mother. On the other hand, father goes to office in daytime and he would be back at evening and just asks the children about day activities because he is the head of family. The second difference between both pictures is behaving pattern. If we see the picture of child, it can be seen that, when mother enters in the room, child wakes up and greeting mother in an impolite way but replies his father with respect and polite manner because love and affection are female characteristics. Moreover, mother has raised her hand and replying her son but father is standing in a distance and asking his son because boss would be friendly with other people. So father is the head or boss in the family.

\section{Promoting Glass Ceiling in Children's School Books}

Glass Ceiling is a term used by different Sociologists to study the gender discrimination in different aspect (i. e Education, Economics, Politics etc) of society. Federal Glass Ceiling Commission defined that it is "the unseen, yet unreachable barrier that keeps minorities and women from rising to the upper rungs of the corporate ladder, regardless of their qualifications or achievements (1995, P. 4). Generally, Pakistani society believes that woman cannot run administration system due to different weakness.
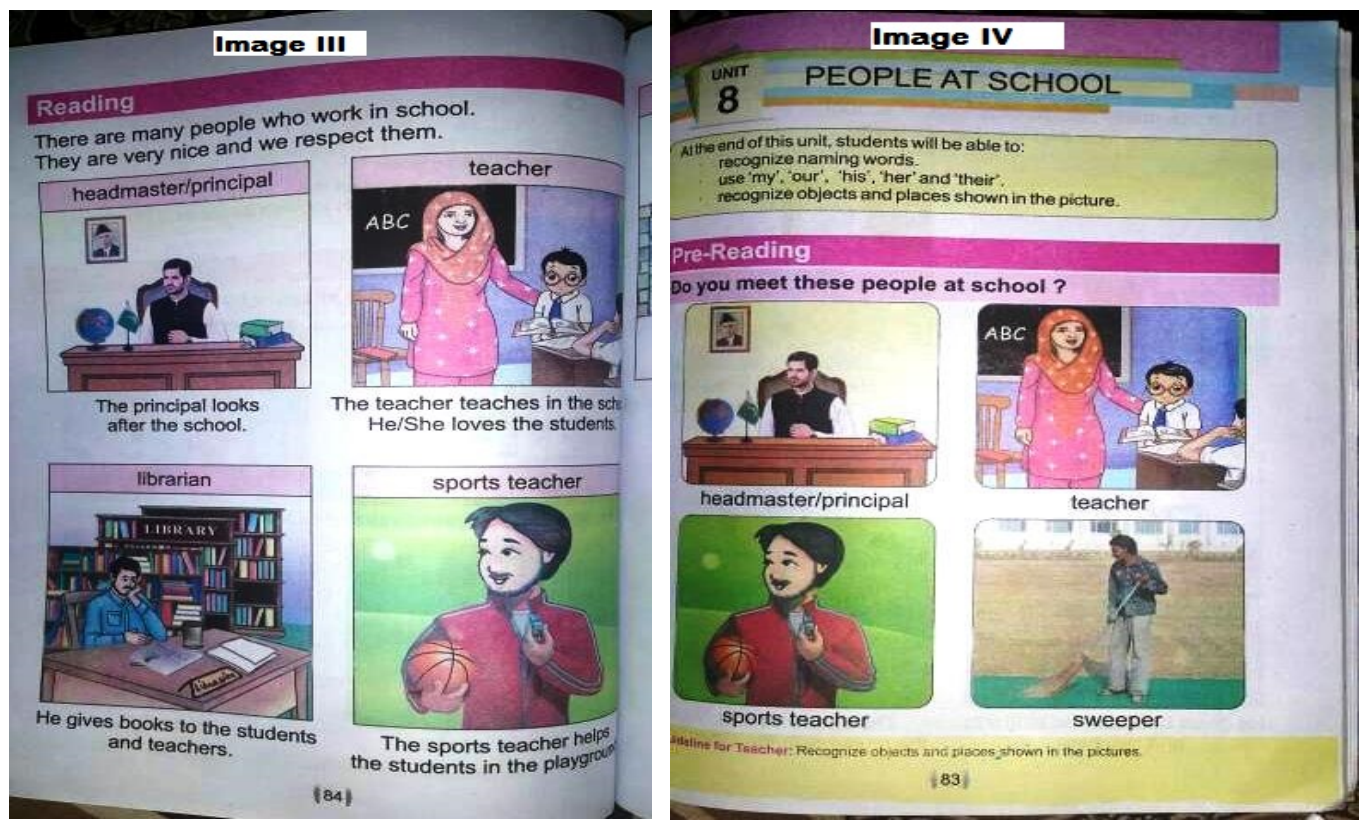
Similarly, stereotypical realities are propagated in schools textbooks. There are four pictures in Image iii. Image is taken from an English book, which is taught to third grade students in government schools of Balochistan. In Image iii, first picture is a Headmaster/principal who is a man, second one is a female teacher with her students, third one is a librarian who is a man and fourth one is a male sport teacher. This image clearly depicts that male can only be a head of institution as well as homes because males are serious, energetic, strong and leaders. Leading jobs are signed to males and females are considered weak and followers. So such jobs are assigned to females in the society. On the other hand, second picture, female teacher who has put her hand on little child which is the sign of love. Teaching is a feminine job because females are sober, lover and easy job for females. Though women can be the head of institutions, they are not given the chance to go upper positions because of Glass Ceiling (Wiley, 2012) and bamboo ceiling (Hyun, 2005).

\section{Discussion}

As social constructionists, believe that social realities are constructed by society according to the normative and social structure of society. As French Sociologist Pierre Bourdieu believed that power is constructed by society and it is legalized and justified by social structure and agencies (Pitsoe\&Letseka, 2013). Similarly, it is society who determines the social position and roles of individual the society. Karl Marx also added that material condition such as technology, ability to produce and social relations production determines the society's superstructure (Seligman, 1901).

So, the factors of production, capacity of producing material goods and social relations are owned by most powerful segment of society who are "men" and women are vulnerable, alienated and marginalized group in the society. The social realities are construct by society which support supremacy the dominancy of men and subordination and inferiority of women.

Similarly, it is clear from the above given data that women are represented as inferior, obedient, subordinate and men are portrayed as owner, dominancy, supremacy of male members of society in School Textbooks of Balochistan.

School Textbooks of Balochistan are promoting and perpetuating male supremacy and dominancy. On the other hand, women are rendered as inferior, submissive and dependent. The young generation are taught these biased and discriminatory approaches and they would adopt and practice them in their daily life activities. As Michal Foucault (1980) said that discourse creates knowledge and knowledge has power. The power and knowledge would create and recreate the social 
realities in which we are represented (Pitsoe\&Letseka, 2013). Most importantly, the women have accepted and justified the male hegemony and women believed that realities are in favour of them. The women never resist against male hegemonic power because they believe that it is for the betterment, development and help women to be mainstreamed in the society but actually it is not (Anderson, 1981). It is very necessary to create Counter-Hegemony (Pratt, 2004) against male dominant discourse in school textbooks for promoting equality and egalitarian approach towards women in the society.

The findings of the present study clearly highlights that school textbooks have also representing roles according to the gender of the person. Women are depicted as doing domestic works, which is believed to be in private domain. On the other hand, men are involved in public domains (Ullah \& Skelton, 2013). Male members are found driving, ownerships the houses, decision-making position and external affairs of the family. On the other hand, female members are depicted as teaching, doctors, cooking, cleaning, playing with dolls and emotional and soft works and dealing with internal affairs of the family (Chiponda\& Wassermann, 2011).

Most importantly, the result of the current study highlighted that women are mostly represented in lower positions and men are rendered in highest status which glass ceiling (Cotter. et al., 2001). The above Image No III and IV are clearly showing that women only can teach which is a soft job which is caring and looking after the children in school while men are represented as librarian which is managing position. So, women do not have management qualities and they cannot reach on this position because women are believed to be inferior and weak in the society. So, breaking the discriminatory approach, it needs to follow the counter hegemony against glass ceiling in offices, homes as well as other public domains (Pratt, 2004, Cotter et al., 2001).

Thus, the school textbooks of Balochistan are promoting women biased approaches and perpetuating men supremacy to the young generation. It is dire need to adopt the egalitarian approach while developing the curriculums and schools textbooks for the children. Otherwise, our children would learn negative attitudes and behaviors from textbooks against women. Inequality between men and women would be continued forever which is very dangerous in this modern society.

\section{Conclusions}

The present study is conducted to know the representation of gender in school textbooks of Balochistan. It is found from the study that school textbooks are promoting and perpetuating the women biased and discriminatory messages to the 
next generation. Women are portrayed in traditional 3Cs (Cooking, Cleaning, Childrearing) while men are represented as bread winners, head of families, decision making about family affairs and involved in works which are representing the public domains. Even a small boy can be the head of family and he can introduce the family instead of above 70 years mother. These are occurring due to gender discourse created by society and social structure because school textbooks usually represent the social realities that are prevailing in the society. So, the women should be taken in consideration while developing the curriculums and women should also get equal chance to be presented in textbooks. Textbooks are the only sources from which the children learn the social realities of society. Stereotyping and biased messages should be considered while developing the curriculums for school children.

\section{Recommendations}

It is recommended that the issues of women and women should be taken in confidence while developing the policies and laws regarding education, otherwise, women would be victimized and would be most disadvantaged group in the society. This study is very limited in scope, more studies can be carried out for bring equality and balance in schools textbooks of Balochistan as well as Pakistan because women have similar representation in all schools textbooks of the country. After completion of the curriculums and textbooks, there should an independent committee to check such bigots and prejudiced images, texts, exercises and other literatures in children school textbooks. The curriculums should be non-sexist as well as anti-sexist so that women and men get equal chance of presentation.

\section{References}

Anderson, P. (1981). The Antinomies of of Antonio Gramsci, New left Review. Retrieved on 20, August 2018 from https://newleftreview.org/I/100/perryanderson-the-antinomies-of-antonio-gramsci

Barclay, L. K. (1974). The Emergence of Vocational Expectations in Preschool Children. Journal of Vocational Behavior, vol.4:1, pp.1-14.

Chiponda, A. \& Wassermann, J. (2011). Women in History Textbooks: What Message Does this Send to the Youth? Yesterday and Today, vol.:6, pp.1325.

Cotter, D. A., Hermsen, J. M., Ovadia, S. \&Vanneman, R. (2001). The Glass Ceiling Effect. Social Forces, vol.80:2, pp.655-681. 
Eagleton, T. (1991). Ideology, an introduction. London and New York.

Faiz, J. (2015). Politics of Education, Conflict and Conflict Resolution in Balochistan, Pakistan (Doctoral Dissertation, University of Westminster).

Federal Glass Ceiling Commission. (1995). Solid Investments: Making Full Use of the Nation's Human Capital. Washington, DC: US Department of Labor, 4.

Foucault, M. (1980). Language, Counter-Memory, Practice: Selected Essays and Interviews. Cornell University Press.

Foucault, M. (2012). Discipline and Punish: The birth of the Prison. Vintage.

Henslin, J. M., Possamai, A. M., Possamai-Inesedy, A. L., Marjoribanks, T. \& Elder, K. (2015). Sociology: A Down to Earth Approach. Pearson Higher Education AU.

Henslin, J. M. (1981). Down to Earth Sociology:: Introductory Readings. Simon and Schuster.

Hyun, J. (2005). Breaking the Bamboo Ceiling: Career Strategies for Asians. New York: Harper Business.

Jabeen, S. \& Ilyas, A. (2012). Gender Role Modelling in Textbooks: Case Study of Urdu Textbooks of Sindh Province. Pakistan Journal of Women's Studies, vol.19:1.

Kittelberger, L. M. (2002). Gender bias: changes in portrayal of women in children's literature from 1955-1960 to 1995-2000(Doctoral dissertation, Pennsylvania State University).

Khurshid, K., Gillaniz, I. G. \& Hashmi, M. A. (2010). A Study of the Representation of Female Image in the Textbooks of English and Urdu at Secondary School Level. Pakistan Journal of Social Sciences (PJSS), 30(2).

Kolbe, R. \& La Voie, J. C. (1981). Sex-Role Stereotyping in Preschool Children's Picture Books. Social Psychology Quarterly, 369-374. 
McCabe, J., Fairchild, E., Grauerholz, L., Pescosolido, B. A. \& Tope, D. (2011). Gender in Twentieth-Century Children's Books: Patterns of Disparity in Titles and Central Characters. Gender \&Society, vol.25:2, pp.197-226.

Mendoza, J. \& Reese, D. (2001). Examining Multicultural Picture Books for the Early Childhood Classroom: Possibilities and Pitfalls. Early Childhood Research \& Practice, vol.3:2, p.2.

Pitsoe, V. \& Letseka, M. (2013). Foucault's Discourse and Power: Implications for InstructionistClassroom Management. Open Journal of Philosophy, vol.3:01, p.23.

Pratt, N. (2004). Bringing politics back in: examining the link between globalization and democratization. Review of International Political Economy, 11(2), 311-336.

Seligman, E. R. (1901). The Economic Interpretation of History. I. Political Science Quarterly, 612-640.

Shah, N., Sultan, R. S. \& Kaker, B. Balochi Oral Literature and Gender Construction. Pakistan Journal of Gender Studies, 16 (17), 89-102.

Singh, M. (1998). Gender issues in children's literature. ERIC Clearinghouse on Reading, English, and Communication.

Simpson, J. \& Weiner, E. S. (1989). Oxford English dictionary online. Oxford: Clarendon Press. Retrieved March, 6, 2008.

Stacey, K., Chick, H. \& Kendal, M. (Eds.). (2006). The future of the teaching and learning of algebra: The 12th ICMI study(Vol. 8). Springer Science \& Business Media.

Stromquist, N. P., Lee, M. \& Brock-Utne, B. (1998). The Explicit and the Hidden School Curriculum. In N. P. Stromquist \& K. Monkman (Eds.), Women in the Third World: An Encyclopedia of Contemporary Issues, pp.397-407, New York: Garland Publishing.

Taylor, F. (2003). Content Analysis and Gender Stereotypes in Children's Books. Teaching Sociology, vol.31:3, pp.300-311.

Tsao, Y. L. (2008). Gender Issues in Young Children's Literature. Reading Improvement, 45(3), 108-114. 
Trepanier-Street, M. L. \& Romatowski, J. A. (1999). The Influence of Children's Literature on Gender Role Perceptions: A re-examination. Early Childhood Education Journal, 26(3), $\quad$ 155-159.

Ullah, Hazir(2016) School Teaching As a Feminine Profession: The Legitimization And Naturalization Discourses In Pakistani Context. In: Papers from the Education Doctoral Research Conference 2015. University of Birmingham, Birmingham, pp. 122-130.

Ullah, H. \& Skelton, C. (2013). Gender representation in the public sector schools textbooks of Pakistan. Educational Studies, 39(2), 183-194.

Weitzman, L. J., Eifler, D., Hokada, E. \& Ross, C. (1972). Sex-role socialization in picture books for preschool children. American journal of Sociology, 77(6), 1125-1150.

Wiley, John (2012). The Blackwell Encyclopedia of Gender and Sexuality Studies. Vol. 5. John Wiley and Sons.

Dr. Rana Saba Sultan is Professor in the Department of Sociology, University of Karachi.

Nadil Shahis M.Phil. Scholar in the Department of Sociology, University of Karachi, Pakistan.

Ambreen Fazal is an Assistant Professor in the Department of Media Studies, Sindh Madressatul Islam University. 